\title{
Musculocutaneous neuropathy after anaesthesia for thyroid surgery: a case report
}

\author{
Tiroid cerrahisi anestezisi sonrasında gelişen muskulokutanöz sinir nöropatisi: \\ olgu sunumu
}

\author{
Emine ÖZYUVACl, ${ }^{1}$ Abdullah Tolga şitiLCi, ${ }^{2}$ Anupama WADHWA ${ }^{3}$
}

\begin{abstract}
Summary
Postoperative isolated injury of the musculocutaneous nerve is a rare disorder and complication. Reported cases are claimed to present with loss of biceps and brachialis power without neuropathic pain. When injury occurs to one of the terminal branches of the brachial plexus, the lateral cutaneous nerve of the forearm, pain is the major symptom and it typically radiates along the radial aspect of the forearm. In the literature, isolated lesions of the musculocutaneous nerve have been attributed to repeated microtrauma, indirect trauma or direct trauma to the nerve. It may also occur due to strenuous extension of the forearm for prolonged periods.
\end{abstract}

Key words: Lateral cutaneous nerve; musculocutaneous nerve; neuropathy; patient positioning; postoperative pain.

\begin{abstract}
Özet
Postoperatif muskulokutanöz sinir hasarı nadir bir sorun ve komplikasyondur. Bildirilen vakalarda bu sinirin hasarı sonucunda, nöropatik ağrı olmaksızın bisesps ve brakialis kaslarında güç kaybı olduğu yazılmıştır. Brakiyal pleksusun, lateral kutanöz siniri gibi terminal dallarından birinde hasar oluştuğu zaman majör belirti ağrı olup; bu ağr ön kolun radial yüzüne doğru yayılir. Literatürde izole muskulokutanöz sinir hasarılarının, tekrarlayan mikrotravmalar ve sinirin indirekt veya direkt travmaya maruz kalmast nedeniyle oluştuğu bildirilmiştir. Izole muskulokutanöz sinir hasarı ayrıca, ön kolun uzun süre boyunca ekstansiyonda kalmasina bağgh da oluşabilir.

Anahtar sözcükler: Lateral kutanöz sinir; muskulokutanöz sinir; nöropati; hasta pozisyonu; postoperatif ağrı.
\end{abstract}

\footnotetext{
'Department of Anaesthesiology and Reanimation, Istanbul Education and Research Hospital, Istanbul, Turkey; ${ }^{2}$ Oral and Maxillofacial Surgery, Department of Anaesthesiology, Istanbul University, Dentistry Faculty, Istanbul, Turkey; ${ }^{3}$ Department of Anesthesiology and Perioperative Medicine, University of Louisville, Louisville, Kentucky, USA 'Istanbul Eğitim ve Araştırma Hastanesi, Anesteziyoloji ve Reanimasyon Bölümü, ístanbul; 2istanbul Üniversitesi Diş Hekimliği Fakültesi, Ağız, Diş-Çene Hastalıkları Cerrahisi Anabilim Dalı, Anesteziyoloji Bölümü, İstanbul; ${ }^{3}$ Louisville Üniversitesi Araştırma Konsorsiyumu, Anesteziyoloji Bölümü, Louisville, Kentucky, ABD
} 
Postoperative isolated injury of the musculocutaneous nerve is a rare disorder and complication. Reported cases are claimed to present with loss of biceps and brachialis power without neuropathic pain. ${ }^{[1-3]}$ When injury occurs to one of the terminal branches of the brachial plexus, the lateral cutaneous nerve of the forearm, pain is the major symptom and it typically radiates along the radial aspect of the forearm. ${ }^{[1,4]}$ In the literature, isolated lesions of the musculocutaneous nerve have been attributed to repeated microtrauma, indirect trauma or direct trauma to the nerve. ${ }^{[5]}$ It may also occur due to strenuous extension of the forearm for prolonged periods.

\section{Case Report}

A-41-year old euthyroid patient presenting with a goiter underwent a bilateral total thyroidectomy. Preoperative evaluation was normal. She was on no medications and had no history of prior surgery. She was ASA I with no health issues. Anaesthesia induction, intubation and maintenance were uneventful, with a normal postoperative course. The duration of surgery was 5 hours. During the procedure, the right arm was adducted and the left arm was abducted, with padding at the pressure points.

The patient was discharged from the hospital on the second postoperative day. However, one week after the surgery, she complained of sharp stabbing and burning pain starting at the axilla and radiating over the medial aspect of the left arm, continuing to the radial antebrachial region.

She was referred by the department of surgery to the pain clinic. On physical examination, minimal tenderness was observed on the forearm and over the arm. There was $2 / 5$ sensory deficit in the antecubital fossa and the inner portion of the forearm and 2/5 motor deficit in the biceps, coracobracialis and brachialis muscles. The range of motion of the shoulder and elbow was limited and the movement was painful. X-ray revealed a normal bony structure of the shoulder and a chest radiograph was normal. A shoulder MRI was performed and it was normal. The rotator cuff and the other soft and bony tissues were normal. The distribution of pain in the forearm was in accordance with the distribution of the lateral cutaneous nerve of the forearm. Examination for lateral epicondylitis and radial tunnel syndrome was normal. The pain started from the axilla and the distribution of pain was in line with the track of the musculocutaneous nerve. The possibility of a more proximal injury to this nerve was considered. Electrodiagnostic examination (EMG: Electromyography) showed that the patient had suffered an isolated and serious left musculocutaneous nerve axonal injury. In addition, the left median sensory nerve onset was $2.6 \mathrm{~ms}$ at the second digit; the right superficial radial sensory nerve onset was $1.7 \mathrm{~ms}$, the left superficial radial sensory nerve onset was 1.7 $\mathrm{ms}$, and the left ulnar sensory nerve onset was 2.8 $\mathrm{ms}$ at the fifth digit. Testing the reminder of the upper extremity musculature and paraspinal muscles did not reveal additional spontaneous activity.

The patient was referred to the physical rehabilitation medicine clinic. Physical therapy and medications were started at the same time. We started her on gabapentin $1200 \mathrm{mg}$ daily, which was progressively increased to $3600 \mathrm{mg}$ daily, NSAIDs (paracetamol $325 \mathrm{mg}$ and tramadol hydrochloride $37.5 \mathrm{mg}$ ) plus a tricyclic antidepressant. The patient received corticosteroid injection to the subcoracoid region at 3-week intervals for 3 months. By the end of the 3rd month, she reported no further painful episodes.

\section{Discussion}

The ulnar nerve is the most common nerve to be injured during surgery because its superficial position leaves it vulnerable to compression. The mechanism of injury to the musculocutaneous nerve has been reported to be strenuous and vigorous exercise, which contracts the biceps muscle against resistance during flexion and pronation of the elbow. ${ }^{[1]}$ Isolated musculocutaneous nerve injury has also been reported after surgical procedures due to compression of the nerve arising from improper positioning. ${ }^{[3,6]}$ In the literature, isolated lesions of the musculocutaneous nerve have been reported due to repeated microtrauma, indirect trauma, or direct trauma to the nerve. Musculocutaneous nerve injury can occur proximally, where it painlessly affects biceps strength and sensation in the forearm, or it can occur more distally, near the elbow crease, where it is 
purely a sensory syndrome, accompanied by pain. ${ }^{[7]}$

Musculocutaneous neuropathy is also described in the literature in a 37-year-old male presenting 5 weeks after moving large rolls of yarn. ${ }^{[8]}$ Compression may also be a cause for isolated musculocutaneous neuropathy, as reported in a 22-year-old male who presented with painless weakness in the biceps brachii in the morning after playing recreational basketball. ${ }^{[9]}$ Our patient had pain and weakness from the axilla to the radial antebrachial region. An isolated musculocutaneous nerve injury has also been reported in the literature in a 21 -year-old male following a 10-hour surgical procedure in which both arms were positioned in external rotation and abduction at approximately $90^{\circ} .{ }^{[3]}$ A similar case was reported by Besleage et al., ${ }^{[10]}$ who described the case of a 55-year-old female who complained of numbness, weakness, and pain throughout the arm, starting 1 day following a surgical procedure. The pain was noted predominantly at the right shoulder girdle and radiated down the right arm to the thumb. Musculocutaneous nerve injury, besides being rare, may present with an atypical clinical picture, and the objective finding may be seen by MRI imaging and EMG examination. We were unable to find any abnormality in MRI images. Our case was easy to diagnose and was unique in its symptoms and findings. Although the mechanism of injury in the present case was similar to that previously reported in the literature, the clinical picture was somewhat different.
Our patient responded to conservative treatment and steroid injections and reported relief from symptoms following physical therapy and medications. We have to remain alert with respect to intraoperative patient positioning and postoperative pain in the extremities, as it can cause serious clinical symptoms.

\section{References}

1. Yilmaz C, Eskandari MM, Colak M. Traumatic musculocutaneous neuropathy: a case report. Arch Orthop Trauma Surg 2005;125(6):414-6.

2. Braddom RL, Wolfe C. Musculocutaneous nerve injury after heavy exercise. Arch Phys Med Rehabil 1978;59(6):290-3.

3. Dundore DE, DeLisa JA. Musculocutaneous nerve palsy: an isolated complication of surgery. Arch Phys Med Rehabil 1979;60(3):130-3.

4. Osterman AL, Babhulkar S. Unusual compressive neuropathies of the upper limb. Orthop Clin North Am 1996;27(2):389408.

5. Alberta FG, Elattrache NS. Diagnosis and treatment of distal biceps and anterior elbow pain in throwing athletes. Sports Med Arthrosc 2008;16(3):118-23.

6. Pećina $M$, Bojanić I. Musculocutaneous nerve entrapment in the upper arm. Int Orthop 1993;17(4):232-4.

7. DeFranco MJ, Schickendantz MS. Isolated musculocutaneous nerve injury in a professional fast-pitch softball player: a case report. Am J Sports Med 2008;36(9):1821-3.

8. Sander HW, Quinto CM, Elinzano H, Chokroverty S. Carpet carrier's palsy: musculocutaneous neuropathy. Neurology 1997;48(6):1731-2.

9. Juel VC, Kiely JM, Leone KV, Morgan RF, Smith T, Phillips LH 2nd. Isolated musculocutaneous neuropathy caused by a proximal humeral exostosis. Neurology 2000;54(2):494-6.

10. Besleaga D, Castellano V, Lutz C, Feinberg JH. Musculocutaneous neuropathy: case report and discussion. HSS J 2010; 6(1):112-6. 